\title{
Uneasy lies the heart that wears a badge: James Gray's We Own the Night as a Gen-X Henriad*
}

\author{
Inmaculada N. Sánchez-García \\ Northumbria University; Newcastle University, UK
}

\begin{abstract}
This article analyses James Gray's We Own the Night (2007) as a cinematic retelling of Shakespeare's Henriad that presents Hal's story not as the chivalric redemption of a national hero but as a tragic fall from happiness. Through close comparative reading of these texts, I explore how We Own the Night rewrites Hal's story as a (post)modern tragedy which addresses the concerns of the so-called Generation X. Hal's liminal position-caught between opposing social worlds of crime and law - presents the narrative's major conflict, which itself echoes Jan Kott's tragic vision of Shakespeare's play.

KEYWORDS: James Gray, Henriad, Prince Hal, Generation X, Filmic Shakespeare

\section{Inquieto está el corazón que lleva una insignia: We Own the Night de James Gray como adaptación de Enrique IV} para la Generación $X$

RESUMEN: Este artículo analiza We Own the Night (dir. James Gray, 2007) como una adaptación cinematográfica del drama de Enrique IV que presenta la historia de $\mathrm{Hal}$ no como la redención caballeresca de un héroe nacional sino como una caída trágica. A través del análisis comparativo de estos textos, el presente artículo indaga en la forma en que We Own the Night reescribe la historia de $\mathrm{Hal}$ como una tragedia (post)moderna que se relaciona con la problemática de la Generación X.

Inquieto o coração que usa um distintivo: We Own the Night, de James Gray, como uma adaptação de Henrique $I V$ para a Geração $X^{*}$

RESUMO: Este artigo analisa We Own the Night (2007), de James Gray, como uma adaptação cinematográfica do drama de Henrique $I V$, que apresenta a história de Hal não como uma redenção de cavalaria de um herói nacional, mas como uma queda trágica a partir de um estado de felicidade. Por via de uma leitura comparativa atenta destes textos, exploro de que forma We Own the Night reescreve a história de Hal como uma tragédia (pós) moderna que chama a atenção para as
\end{abstract}

\footnotetext{
* I am very grateful to Clara Calvo, as this paper stems from the BA thesis (i.e. TFG) that I wrote under her supervision in Murcia University. Thank you, Clara, for all your help and for encouraging me to publish this piece even before my academic career had started. I am also very grateful to Monika Smialkowska, Jacky Collins, and Anamarija Horvat, who were wonderful readers of earlier drafts of this paper and provided me with their invaluable insights.
}

* Translation into Portuguese by Miguel Ramalhete. 
La posición liminal de Hal - sometido a fuerzas opuestas de las esferas del crimen y de la ley - representa el conflicto narrativo central, que a su vez se correlaciona con la visión trágica de Jan Kott sobre la obra de Shakespeare.

PALABRAS ClAVE: : James Gray; Enrique IV; Príncipe Hal; Generación X; Shakespeare en el cine. preocupações da chamada Geração X. A posição liminar de $\mathrm{Hal}$ - preso entre forças opostas da esfera social do crime e da lei-representa o conflito narrativo central, que por sua vez ecoa a visão trágica de Jan Kott da peça de Shakespeare.

PALAVRAS-CHAVE: James Gray; Henrique IV; Príncipe Hal; Geração X; Shakespeare no cinema.

The New York Times film critic A. O. Scott describes We Own the Night (dir. James Gray, 2007) as "a bloody, passionate melodrama, selfconsciously Shakespearean," to which he adds, "or Biblical, or Greek, take your pick of atavisms" (2007, E18). His remark suggests that, by drawing on these canonical precedents, the film aspires to the status of a modern version of a grand, epic narrative. Similarly, the director and screenwriter James Gray hints that evoking an established, "classical" authority may have been on his mind when he considered making a film indebted to Shakespeare's Henry IV plays: "I had read Henry IV Parts I and II, and I thought, what if I told a Shakespearean story, a classicist story, in the context of the world of the police?"1 A. O. Scott may be willing to dismiss the Shakespearean connection as a nostalgic appeal to venerable but outdated patterns, as illustrated by his ironic use of the word "atavism." However, this article proposes that We Own the Night uses Shakespeare in much more productive and meaningful ways. A careful analysis of its Shakespearean echoes sheds light on the ways in which the film relates to the anxieties of the so-called Generation X. By assembling and mobilizing parts of the plot and themes of the Henriad, particularly 1 Henry IV, the makers of We Own the Night partake in a long tradition of creative practitioners who see Shakespeare as "compendia of traces of the past, available to be recycled according to present needs and desires rather than as objects of veneration and nostalgia" (Cartelli and Rowe 2007, 34). This active engagement with the past helps them to achieve their artistic and ideological aims of conducting an examination of current socio-

\footnotetext{
${ }^{1}$ As Gray remarked when interviewed by Andrew Tracy, which is a paratextual acknowledgement that can also be found in other press articles (Lim 2007; Kaganski 2013; and O'Hehir 2011). For a discussion of James Gray as an auteur see Alpert (2012) and Mintzer (2012).
} 
political issues, particularly the tension between individual happiness and social conformity.

Before discussing these issues, it is worth pausing to consider what We Own the Night tells us about adaptation as a scholarly discipline. It may seem surprising that a widely screened and distributed film, featuring major Hollywood stars, such as Eva Mendes, Mark Wahlberg, Joaquin Phoenix, and Robert Duvall, has been largely ignored by Shakespeare scholars until Douglas Lanier's recent and remarkable contribution in Shakespeare Bulletin on December 2016. ${ }^{2}$ Lanier proposes that Gray's film is an important Shakespearean adaptation which merits further attention from Shakespeare scholars, a suggestion that this article takes up and develops. But if a Cannespremiered, independent box-office hit, such as We Own the Night, is an easily demonstrable re-telling of a major Shakespeare play, why has it passed unnoticed for almost a decade? The answer may lie in the persistence of the notion of fidelity in evaluating adaptations, despite well documented theoretical challenges to that notion. ${ }^{3}$ Most likely, the film has been neglected by adaptation studies for so long because its engagement with Henry IV is indirect and highly imaginative, as evidenced by the lack of any direct reference to Shakespeare's play and extensive changes to its plot, setting, and characterization. This invites reflection, since in our allegedly "postfidelity" era we should be ready to study the "increasingly heterogeneous and fragmentary presence of 'Shakespeare," simultaneously visible and invisible (Calbi 2013, 2). ${ }^{4}$ Saviour Catania points out that "spectrality is the soul of adaptation," since every text originates "not only from a source text but, just as crucially, from a myriad of influences" (2017, n.p.). Such an understanding of

\footnotetext{
2 We Own the Night premiered in Cannes and was a commercial success in the United States, both at the cinemas and later when it was released in DVD format, as the financial information of the film shows. It was distributed by Columbia Pictures and Universal.

${ }^{3}$ The emergence of intertextuality and poststructuralism in the eighties challenged fidelity criticism (Naremore 2000, 7-12; Stam 2015, 8; Ray 2000, 45; Aragay 2015, 20-28), with for example the Barthesian notion of text as tissue, which contributed to the move away from an essentialist paradigm where an Author-God instills the text with his socalled "genius."

${ }^{4}$ As for example, Strange Illusion, The Bad Sleep Well or Tron: Legacy. See, respectively, Douglas Lanier (2014), Mark Thornton Burnett (2013) and Laura Campillo (2015) for a discussion of each film in relation to Shakespeare.
} 
adaptation echoes the notion of intertextuality, which has played a major role in the discipline for a long time, with a critical turn "from a discourse of 'fidelity' $[\ldots]$ towards a discourse of intertextuality" (Stam 2017, n.p.). In 2008, Thomas Leitch observed that the longing for faithful adaptations remained unchallenged in critical practice, despite the theoretical pronouncements against it. Leitch argues that we still need "to wrestle with the un-dead spirits that continue to haunt [the field] however often they are repudiated" $(2008,64)$. The re-launch of the Literature/Film Quarterly as LFQ in the spring of 2017 demonstrates that these spirits keep coming back, as fidelity features in numerous articles in the issue, despite the new directions the scholarly discipline is taking in an increasingly mediatized world.

Since fidelity refuses to disappear from discussions of film adaptation, we may need a new perspective from which we can address this issue, and We Own the Night can assist us in this task. Instead of trying to liberate adaptations from the limiting discourse of fidelity, we can shift the focus by applying Jack Halberstam's concept of "the queer art of failure" to adaptation studies and thus embrace "failure" as part of adaptation. Halberstam's theorization of failure calls for "ways of being and knowing that stand outside of conventional understandings of success" $(2011,2)$. One can argue that every adaptation is doomed to fail from the start since, in the words of Thomas Leitch,

most citizens [...] think along eminently predictable lines: the book is better; they never should have done the movie; it's nothing but commercial exploitation of (take your pick) either a work of literary art too inimitably fine to adapt or a piece of sub-literary trash that should have been left to die unadapted. (2017, n.p.)

According to conventional understandings of film adaptation, such as those stated above, it is hardly possible for any cinematic retelling of a text to be satisfactory, or in other words, to be a success. Therefore, why not accept "failure" from a queer perspective? Namely, failure as a liberating force that offers us new methods for evaluating cinematic adaptations and disrupts normative binaries of failure and success. As Halberstam explains, re-evaluating the notion of failure can serve "as a way of refusing to acquiesce to dominant logics of power and discipline and as a form of critique" of normative discourses that encourage success $(2017,88)$. Interpreting adaptations through Halberstam's approach to failure would help us to dispense with 
privileging one, unified, self-centered reading and to shift critical focus to alterity and an understanding of a text as open to multiple interpretations, editions, and alteration.

We Own the Night can be seen as a good test case for theorizing adaptation as failure not only because it is a box-office hit that passed unnoticed in adaptation studies for a decade, but especially because it queers conventional understandings of failure and success. As I will explain, the film avoids a clear-cut ending and the protagonist simultaneously fails and succeeds. The film transgresses these paradigms by presenting a narrative in which the protagonist fails by succeeding in becoming a policeman. I propose an alternative interpretation to Lanier's reading of We Own the Night as a reworking of Henry IV "in which the prince willingly chooses family love and civic duty over personal pleasure and independence" (2016, 465-66). Instead, I read the film as a postmodern retelling of Hal's story with an ideologically constrained protagonist, who has limited freedom and struggles to navigate a system that does not satisfy the promises set by the so-called American Dream. Accordingly, instead of interpreting the film as going "against prevailing critical accounts of Shakespeare's play" (Lanier 2017, 466), this article argues that Gray's adaptation of Henry IV reflects Jan Kott's influential analysis of the play. Kott's bleak interpretation of the History plays maintains that human agency is limited by what he calls the Grand Mechanism of History, which is the social structure in which the protagonists are immersed. This article offers an exploration of We Own the Night in light of Althusser's notion of ideology, hereby situating the adaptation within established critical accounts of the Henriad. Similarly, considering how most of the twentieth century adaptations of Henry IV focus on Hal instead of Falstaff (Kastan 2002, 96), James Gray's update of Hal's story partakes of this trend too, adding to the list of these latest adaptations. Bobby Green functions as a twenty-first century Hal, whose reformation takes center-stage. Therefore, the first part of the article explores Bobby-as-Hal's centrality in the film, while the second part focuses on Bobby's identity struggle in relation to its socio-cultural context as well as to Althusser's ideas and Kott's reading of the Henriad. 


\section{A prince in El Caribe: From reveler to policeman}

Set in late 1980s New York at the climax of the drug war, We Own the Night tells the prodigal story of Bobby Green (Joaquin Phoenix). Bobby is estranged from his family, managing a nightclub owned by Russian émigré Marat Burzhayev (Moni Moshonov), while Bobby's father and brother (Robert Duvall and Mark Wahlberg) lead the narcotics squad of the New York Police Department, and attempt to find Vadim Nesinsky (Alex Veadov), a drug-trafficker and exclusive customer of Bobby's nightclub. This situation poses the two main conflicts developed throughout the film: a private one, as Bobby attempts to assert his individuality in opposition to his family ties, and a public one, through confrontation between the drug-dealers and the police. The clash between these two factions is traced in martial terms and metaphorically referred to as a civil war that is besieging New York. This correlates to Henry IV and the uneasy reign of the first Lancastrian king, with its insurrections in Scotland and Wales and the subsequent war conflicts. The headquarters of the NYPD evokes the English Court of Shakespeare's plays, whilst the nightclub echoes the rebel/criminal underworlds.

The collision of those two domains, and therefore the film's conflict, translates into Bobby's inner anguish: We Own the Night focuses on Bobby and his transformation from wayward son to respectable policeman, inheritor of his father's badge, which is a transition overtly reminiscent of Prince Hal's movement from his "wild years" to his reformation as Henry V. Joaquin Phoenix plays the part of a modernized Prince Hal in his role as Bobby Green, wandering across the margins of New York in the company of his Italian sidekick, Jumbo Falsetti (Danny Hoch), his Puerto Rican girlfriend, Amada Juarez (Eva Mendes), and assorted partygoers and outlaws. The initial thirty minutes of the film provide an eloquent portrayal of Bobby-as-Hal, showing Phoenix's character as a jesting, affectionate and free-wheeling youngster. The opening shot shows him in a bright red shirt while erotically caressing his girlfriend, which is followed by a tracking shot of the protagonist heading to the nightclub's dance floor, where a festive and roaring crowd bids him warm welcome. He is depicted as a Dionysian character inhabiting a world of earthly pleasures, much in consonance with Hal's ale-fueled jesting with Falstaff. 
The introductory sequence of Bobby in the nightclub cuts to a presentation of Burzhayev's clan and Bobby's part in it, where he seems to function as a surrogate son despite the patriarch, Marat Burzhayev, being his employer. These two settings to which Bobby belongs find a counterpoint with Bobby's biological family. Through crosscutting, the film juxtaposes these two sequences in the nightclub and at Burzhayev's home with those of a police celebration in appraisal of the professional achievements of Joseph Grusinsky, Bobby's brother, which functions as a foil to the gleaming club and the affectionate Russian family. Both El Caribe and the police gathering are celebratory events, but while the festivity held at Bobby's club is depicted as one of unrestrained revelry, the latter is infused with a somber hue, as a certain stiffness and restraint permeate the event held, significantly, in a church. The mise-en-scène is revelatory here through the chromatic palette and the set: El Caribe indulges in displaying warm and golden bright colors, together with an intricately carved and ornamented rococo architecture. Conspicuously, the police's party stands out for its functional brutalist architecture with dull colors such as brown and grey that convey the funeral mood of the party. The restraint of Grusinsky's drab celebration echoes the initial words of the king in the Shakespearean text: "So shaken as we are, so wan with care" (1HIV 1.1.1) and the presentation of the domains of order in both play and film act as an indication of their own latent instability at a public and domestic level.

The paradoxical blend of a wan merriment with which Henry IV starts is overtly exposed in the speech given by Joseph Grusinsky, who, in a moment of celebration dutifully asks for a minute's silence to mourn a fallen policeman, with a subsequent doleful toll of the bells highlighting it in the score of the film. The chiming of the bells is supplemented with a series of shots that display Bobby's passionate kissing of his Hispanic girlfriend, furthering the rebellious dimension of the protagonist. It is also significant to note how Joseph addresses the police officers in familial terms: "one of our brothers was killed in the line of duty last night," recalling again the opening speech in 1 Henry IV and its family imagery that functions to assert the unity of the realm after the civil war that deposed Richard II (1HIV 1.1.5-24). Opening with two celebrations that pivot around notions of family and kinship, the two mutually constructive domains with which the film opens give meaning to Bobby/Hal and problematize notions of unity and of the family, as far as he is shown blissfully on the "wrong" 
side, feeling at home away from the bosom of his biological family. In addition, the film's editing technique introduces the two main settings and the narrative conflict through cross-cutting, which echoes its Shakespearean source text and the acute disparity found between the comic and the political scenes, linguistically contrasted through the combination of different registers on the page, alternating verse and prose with Hal pivoting in-between.

The rebels of Shakespeare's text are transported from the Scottish and Welsh courts to the nightclub, where they mingle with migrants and partygoers, subsequently standing closer to Bobby/Hal. This maneuver is a converging movement that not only poses the thieves, revelers and drunkards of the Eastcheap tavern juxtaposed with the rebels, but also foregrounds the rebellious nature of the protagonist and his centrality in the adaptation. Hal owes his nickname as Wild Prince to his teasing mood and his taste for ale but also to his dissolute and riotous behavior. Shakespeare's text portrays a Prince Hal lacking duty and responsibility, a man whose own father describes him as stained by "riot and dishonour" (1HIV 1.1.84). Equally, Bobby is characterized as indulging in an epicurean lifestyle, while also being impetuous, disruptive and freewheeling, eventually behind bars. During a riot in his nightclub, Bobby resists cooperation with the police, confronts the officers and is taken to prison, which is a confrontation with the law reminiscent of the one recalled in $2 \mathrm{HIV}$ (1.2.193-95), as it narrates how Hal assaults the Lord Chief Justice and is subsequently incarcerated.

Neither Bobby nor Hal are morally clear-cut characters, showing an ambiguity epitomized in the famous monologue "I know you all" (1HIV 1.2.185-207). Although Hal certainly shows a chilling, calculating and dubiously moral behavior, his famous monologue implies that he actually assumes his duty as heir to the throne. A similar ambivalence is evident in Bobby: he gives no restraint to his passions, but he is a loving boyfriend; he takes drugs, but he is not a drug-dealer; he gleefully wanders through his nightclub while ignoring his family, but he is totally committed to his job as manager of the club. However, We Own the Night does not have a cinematic equivalent for the dramatic function covered by the "I know you all" monologue, which constitutes a major and eloquent difference between film and play. Hal acts as a Machiavellian figure and a man self-fashioning himself, aware of his place in the world, while Bobby 
is more of a vexed postmodern character attempting to assert his own identity but ultimately fooled and constrained by external and/or social forces.

Despite Bobby being the central figure and the major borrowing from Shakespeare's play, the secondary characters resonate against the Henriad and contribute to the story by building on the protagonist. Burt Grusinsky, Joseph Grusinsky, Jumbo Falsetti, Amada Juarez, Marat Buzhayev and Vadim Nezhinski are these secondary characters, who in a reciprocal interaction define Bobby and are defined by him. Robert Duvall features as Burt Grusinsky, the police chief of the NYPD, and functions as a Henry IV figure. At a political level, the transposition established from court to police headquarters echoes Henry's deposition of King Richard II, which prompted a movement from a de jure King to a de facto ruler, and located regal legitimacy in terms of coercive power. At a private or domestic level, both Henry IV and Burt Grusinsky are suffering fathers worrying for their rebellious, and almost absent, sons. In Richard II, the troublesome relationship between father and son is introduced by the end of the play: "Can no man tell of my unthrifty son?|'Tis full three months since I did see him last" (5.3.1-2). These lines bring attention to a filial absence that is also explicitly noted in the film, as Burt Grusinsky tells Joseph: "It's almost 11. Where's your brother?" to which he adds, once Bobby has arrived: "Been a long time since we've seen you. Your brother says you don't answer the phone anymore [...] What's going on with you?" In the play(s), the king shows his distress by calling his son a "young, wanton and effeminate boy" (RII 5.3.10) and makes even more explicit how he sees his son as stained with "riot and dishonour" (1HIV 1.1.84). At another point, Henry IV compares Hal to Harry Hotspur and wishes "that some night-tripping fairy had exchanged [them]" (1HIV 1.1.86), so that his son were the desired gallant knight. This contrast between the two young Henries in the eyes of the father resurfaces in the film, with Joseph and Bobby as brothers and doppelgangers, although the exemplary warrior, or cop, is already one of Burt's sons, making this interaction yet more evident.

Characterized as a worrying and caring father then, and much committed to his duty as chief and as head of a family, it is duty indeed that leads Burt to the grave, echoing the cause of Henry IV's death: 
PRINCE HAL

Why doth the crown lie there upon his pillow

Being so troublesome a bedfellow?

O polished perturbation! Golden care!

Like a rich armour worn in heat of day,

That scald'st with safety. (2HIV 4.5.20-30)

In these lines, Hal blames the crown as the cause of his father's death, an accusation also made by the King himself during his sleepless night soliloquy that ends with: "uneasy lies the head that wears a crown" (2HIV 3.1.31). This is a line that in the film could be rephrased replacing the monarchic signifier with the updated one - "uneasy lies the heart that wears a badge" - , given how crown and badge function in similar ways: as signs of duty, order and distress that are finally inherited by the offspring.

Henry Hotspur, "the king of honour" (1HIV 4.1.43-52), embodies the code of chivalry and is adapted by Shakespeare departing from the Chronicles to make him of the same age as Hal, a departure that locates them as virtual brothers (Weil and Weil 2007, 24). The two Henries stand as kin but polar characters: while one embodies honor the other endorses its opposite. In Gray's film, this symbolic brotherhood is made literal with Joseph Grusinsky being the doppelganger of Bobby at the same time that he is his biological brother. While Shakespeare's play presents a Hotspur that moves from being a chivalric warrior loyal to Henry IV to being a rebel siding with the Scottish uprising, the film presents a fluid Hotspur figure, shifting from Joseph Grusinsky, a police officer of great distinction, to Vadim Nezinsky, the foremost Russian drug-dealer.

As Herbert and Judith Weil argue, Hotspur is a "sober, loyal and hard-working supporter of the rebellion against Richard II" $(2007,24)$, resembling Joseph in his role as laureate police officer. The affection Henry IV shows towards Hotspur in the opening scenes of 1 Henry IV is analogous to the fondness Burt Grusinsky, the Henry's parallel authority figure, conveys in his brief speech at the celebration of Joseph's virtues as a police officer. Joseph's warrior-like quality is enforced when he literally fights against his brother Bobby at the headquarters of the NYPD, as Joseph reacts impetuously to Bobby's infantile provocations. Hal's parody of Hotspur (1HIV 2.4.99-108) in the play exaggerates the martial nature of Henry Percy and reinforces his characterization as a committed follower of the chivalric code. 
Joseph's devotion to the police force functions to the detriment of his role as husband and father, exemplified in the spectral presence of his worrying wife in the film. Just brief glimpses of his wife are given (indeed, we do not even know her name) as she is literally marginalized, echoing the relationship between Hotspur and Kate, who is almost nonexistent to him. ${ }^{5}$

Once Joseph is shot by Vadim, and passes from the battlefield to paper-work administration, Vadim takes over Hotspur's role as the exemplary warrior. Being the chief drug-dealer sought by the police, Vadim mirrors Hotspur insofar as he impersonates the rebellious side of the knight, and a non-hegemonic national identity; while Vadim is a Russian migrant and drug dealer in the US, Hotspur joins the Scottish faction in the war launched against the English status quo. In addition, Vadim is Bobby's scapegoat to achieve redemption: "Harry to Harry shall, hot horse to hot horse, | Meet and ne'er part till one drop one a corpse" (1HIV 4.1.121-22), which is visually rendered in the final battle-like gun exchange and the prostrate corpse of Vadim.

Departing from traditional and straightforward forms of adaptation, We Own the Night provides a triad of Falstaffs. As Douglas Lanier notes, Gray's "characters are often better understood as Shakespearean composites than simple updates" $(2016,463)$, although for him Falstaff is split in two-Amada, and Falsetti, but not Marat. I argue that Falstaff is a composite of all three characters. Each one assumes one of the three features that Simon Callow ascribes to Falstaff, who is an embodiment "of playfulness, of anarchy, of desire" (qtd. in Melchiori 2007, 68). Jumbo is linked to playfulness, Marat to anarchy and Amada to desire. All of them are migrants and thus outsiders, being part of peripheral nationalities in the US - Italian, Russian and Hispanic, respectively - and eventually rejected by the American police officer after his reformation and alignment with the side of order.

Standing for the jocose side of Falstaff, Jumbo Falsetti is parallel to Jack Falstaff - with his name, "jumbo" meaning huge and bulky mass, and his surname and initials pointing towards the Shakespearean character. Jumbo is Bobby's best friend, surrogate brother, and the

\footnotetext{
${ }^{5}$ Joseph and his father Burt are photographed at the celebration held in honor of Joseph's achievements, who calls his (male) child to appear in the photo, but not his wife, who remains seated apart.
} 
source of jokes and laughter, as well as of beer and weed. However, Jumbo's disclosure of information to the drug dealers provokes the transformation of Hal's words at the moment of his coronation (2HIV 5.5.47-63) into kicks and blows. Bobby assaults his friend in an alley because Jumbo has betrayed him, after which Bobby's sidekick is not going to appear on screen again-being, thus, banished from the frame.

Amada, whose name in Spanish means "beloved," is the most important individual in the protagonist's life in the underworld and the film's embodiment of desire. Bobby's girlfriend stands for the Falstaffian quality of desire not only in relation to Bobby, but also in her role as a good-bad girl type, which is a derivative of the femme fatale. Just as Falstaff is rejected for the sake of good government, the subtext of the film tells us how a Puerto Rican woman that dazzles in a hard-boiled masculine environment is not an adequate partner for a respected policeman. Her unsuitability to that sphere is made explicit in the words of Bobby's father: "That Puerto Rican you brought, she been hooking you up?" Burt swiftly deems her as the cause of Bobby's behavior, or, to quote Hal in the play extempore, as a "misleader of youth" (1HIV 2.4.450). She is an inadequate companion for Bobby, as Falstaff is for Hal, because she belongs to a different sphere, marked by differences in race and class. Being part of the underworld, she is not welcome in a higher stratum of society. Amada is also the character that most clearly marks the sacrifice Bobby has to make to cope with his filial duty. The rejection of Amada happens gradually throughout the film, and Hal's premonitory
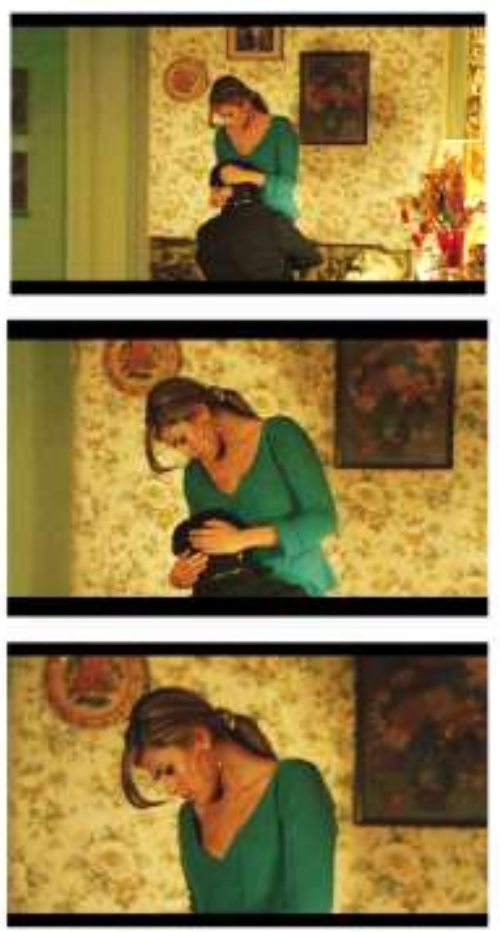

Fig. 1, 2 and 3: Amada's double framing and sustained close-up as a visual counterpart of Hal's "I will, I do." 
words, "I do; I will" (1HIV 2.4.468), find its way visually in the cinematography and mise-en-scène: the framing composition and the camerawork foresee the consequences, as the lens zooms on Amada and a close-up of her figure trapped in a double-frame is arranged, meaningfully, at a point when the narrative would demand attention either on Bobby or on the couple's embrace, considering how the scene corresponds to Bobby's reaction after being informed of the violent assault on his brother. Together with the visual vocabulary, the film narrative shows how Amada is persistently left alone, and Bobby's banishment of Amada coincides with his carefully paced transformation: as the narrative unfolds and he is more and more on the side of the police, consequently she figures less and less in his life.

Falstaff functions also as Hal's surrogate father at Eastcheap, where the commoners in the tavern constitute a warmer family than the one Hal has at court. This is mirrored in the film's opening montage, which unveils how the relationship between Bobby and his father is dysfunctional in comparison to his relationship with Marat. Bobby, welcomed as an adoptive son of the caring Russian family, kisses and addresses Marat with the affectionate "Pop," who listens to him and, unlike Burt Grusinsky, expresses his affection. Marat and Bobby have a reciprocal and healthy father-and-son relationship despite the fact they are employer and employee. Thus, if Falstaff stands as Hal's surrogate father, Marat is the surrogate father to Bobby.

Marat, however, belongs to the drug dealers' sphere and hence is on the rebels' side, with a name pointing towards a famous historical rebel-the leading Jacobine that overthrew the Girondist faction during the French Revolution. Marat sports overt dishonorable attitudes when the film discloses how he has used his grandchildren as a cover for his drug business, in resemblance to the abuse perpetrated by Falstaff in his recruitment of soldiers to gain money (1HIV 4.2.11-47 and 2HIV 3.2.81-293). Eventually, police officers surround the former surrogate father of Bobby, who arrives and commands Marat to kneel down, handing to a fellow officer his biological father's gun - on which the camera focuses with a close-up. Possibly to be read as off-screen assassination, this implied murder resonates towards Falstaff's off-stage death in Henry $V$, where we learn that "the king hath killed his heart" (HV 2.1.88) posing thus king Henry $\mathrm{V}$ as a vicarious murderer of his no longer surrogate father. 
In regard to the development of the narrative arc, We Own the Night structures the story in two parts. The first extends over forty minutes and serves as an introduction to the conflict. The second covers the subsequent seventy minutes, within which the story provides four climactic moments that develop the main movement and concern of the film: the transformation of Bobby Green into Robert Grusinsky. Consequently, the film mirrors the main trajectory established in 1 Henry IV, which corresponds to "Hal's transformation from the truant prince of the tavern scenes to the chivalric hero on the battlefield at Shrewsbury" (Kastan 2002, 7).

The first climactic moment is the spark that ignites the transformation of the protagonist. Once Bobby's brother, Joseph Grusinsky, is shot by Marat and lies on the verge of death, the jesting and frolicking disposition of the prodigal son gives way to his more serious and troubled self. This family-based scene at the hospital, with Bobby accompanying his father and brother while being protected by police officers, significantly without Amada/Falstaff, functions as a cinematic correlative to 1 Henry IV's father-and-son dialogue in act 3 , scene 2 (1-161). Both the film and the play show at this point the protracted transition from a formerly rebellious son to a model one: "I shall hereafter [...] | be more myself" (1HIV 3.2.109-10) and from that moment Bobby begins to side with the police, decides to act as an undercover agent, and to play a "heroic part" during a police infiltration in the base of the drug-dealers.

The second climactic moment corresponds to Bobby's infiltration of the base of the drug-dealers. Shot with a lengthy tracking shot, white aseptic colors, and a score featuring a perturbing white noise, the scene situates Bobby in an alien world. The violent gunfire exchange conveying Bobby's attempt at redemption is rendered as a battle-like epic moment and can be placed as a modern parallel of Shrewsbury. However, as the redemption has not yet ended with the death of Vadim/Hotspur, the film features a second part of Shrewsbury to conclude the narrative.

The third climactic moment corresponds to the death of Burt Grusinsky, which occurs during a car chase in the rain. The dark, confusing, and gloomy environment with which the scene is charged echoes the general climate of unrest, disorder and death that pervades 2 Henry IV. It is an unrest ultimately embodied in the badge-like symbol of the crown, figuratively blamed as the cause of King Henry's 
death. While King Henry IV's death signaled Prince Hal's transformation into King Henry V, Burt's death gives way to Bobby's definitive siding with his family and the police: the official side of order, after enrolling unofficially and illegally with the police. Bobby is issued with a gun and temporary recognition as a policeman, swearing oath to the Constitution, before attending the police academy.

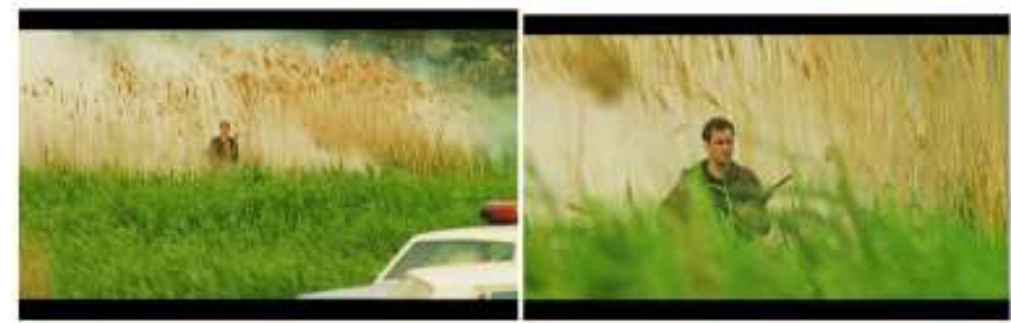

Fig. 4 and 5. Bobby "breaking through the foul and ugly mists" (1HIV 1.2.187-92) created by his fellow police officers.

The fourth and final climax occurs during the final gun battle between the two warring sides at Floyd Bennett Field, a cinematic second equivalent of Shrewsbury. Although Bobby (unofficially) enrolled with the police after his father's death, this scene marks his definitive "reformation" and the flimsy line dividing order and disorder: Bobby does not have to kill Vadim ("Bobby, what are you doing? Bobby! Don't go in there. We have Vadim surrounded") and yet he crosses the line and takes revenge by shooting him to death. Breaking through actual mists after having killed Vadim, he is finally redeemed and performs his part of a prodigal son, to be "wondered at | By breaking through the foul and ugly mists | Of vapours that did seem to strangle him" (1HIV 1.2.191-203). Notably, these "vapours" are artificially created by the police as they throw smoke bombs in the field, an event that together with Bobby/Hal's morally dubious reformation, point towards a subversion/containment mechanism and a certain ethical myopia in the side of (dis)order. The association between mists and the police force also contribute to blur the distinction between the two opposing spheres of order/cops/royals and disorder/drug-dealers/rebels. After the gun battle, the film concludes with a scene showing a celebration of Bobby's graduation as policeman, which functions as the equivalent to Henry V's coronation, both signaling the son's siding with the sphere of order. 
Thus, the film conflates the two final scenes of 1 Henry IV and 2 Henry $I V$ into two consecutive sequences with the figure of Hal/Bobby at their core.

\section{Bobby's dilemma: Seeking identity in the Grand Mechanism}

We Own the Night locates Hal's struggle to choose a side as the key event: both he and Bobby are sons meant to occupy a specific position within a given system or society, aligned with the side of order. As argued above, Hal's reformation, unlike Bobby's, is self-consciously staged-famously conveyed through the "I know you all" soliloquy that is absent in the film. While Hal's perambulations with Falstaff are part of a wider political strategy, Bobby's love affair with Amada and his parties with Falsetti make him genuinely happy. This difference in the level of agency between the play and the film is symptomatic of a movement from a modern Cartesian subject, centered on the human self, to a postmodern, decentered one. ${ }^{6}$

The film does not present the (anti)hero's reformation as a narrative of unproblematic achievement. Even though Bobby redeems himself through Vadim in an epic scene, this event is not presented as an unequivocal victory. By focusing on the protagonist's inner struggle to make sense of his place in the world, the film departs from traditional readings of the play that view Hal's transformation as the chivalric redemption of a young, courageous Prince that eventually becomes an ideal monarch and symbol of a nation. ${ }^{7}$ Instead, We Own the Night tells the story of a fall from happiness, freedom and selfassertion, more akin to the conventions of tragedy than those of a history play. Eloquently in this respect, the film concludes with Bobby's graduation being portrayed not as a cheerful celebration, but with mournful tones conveying grief and sorrow. The film's ending contrasts starkly with its beginning, which encapsulates the overall trajectory triggered since the first climactic moment.

\footnotetext{
${ }^{6}$ Although the modern subject was not fully formed yet, but emerging during Elizabethan times; hence, the difference resides in the dominance of certain philosophical discourses at each historical period. For more on the early modern subject see Greenblatt (1980) and Grady (2000).

${ }^{7}$ As for example Laurence Olivier's cinematic interpretation of Henry $V$.
} 
It is worth comparing the opening and the closing scenes to demonstrate how the film registers the emotional cost of Bobby's siding with his family and with the police. As shown in a subjective shot from the perspective of Bobby during his graduation from the police academy, the protagonist remembers Amada and, by extension, his former "band of brothers" and joyful self. This brief glimpse of Bobby's thoughts and memories not only conveys the character's state of mind but shapes the structure of the film in a circular fashion, bringing us back with the protagonist to the film's opening scene, when an affectionate Bobby appeared with his (banished) girlfriend openly and directly stating his bliss: "I am the luckiest man on the planet [...] if I die now I'd be happy." The cinematography of the opening scene reaffirms Bobby's words as the mise-en-scène shows him caressing his girlfriend in a vibrant lovemaking sequence infused with warm colors. Color functions here in an expressive manner, since the bright palette of red and golden tones conveys Bobby's interiority-his joy and desire. Simultaneously, the characters' movements, with their bodies coalescing, and the fast pace of the editing, register the effervescence of the moment and of Bobby's bliss. This opening scene of love and joy contrasts with Bobby's graduation, which culminates with the protagonist saying to his brother Joseph "I love you too," without looking at him. Not even exchanging glances, they both stand still in a scene colored in cold and somber hues. Grey and dark tones predominate in a scene that visually convey restraint and reflect the general cold and distanced mood of the "celebration." Therefore, this ending scene directly contrasts with the one that opens the film, and substitutes the vibrancy of Blondie's "Heart of Glass" opening soundtrack with a somber graduation speech that ends in "amen" the last word uttered in the film.
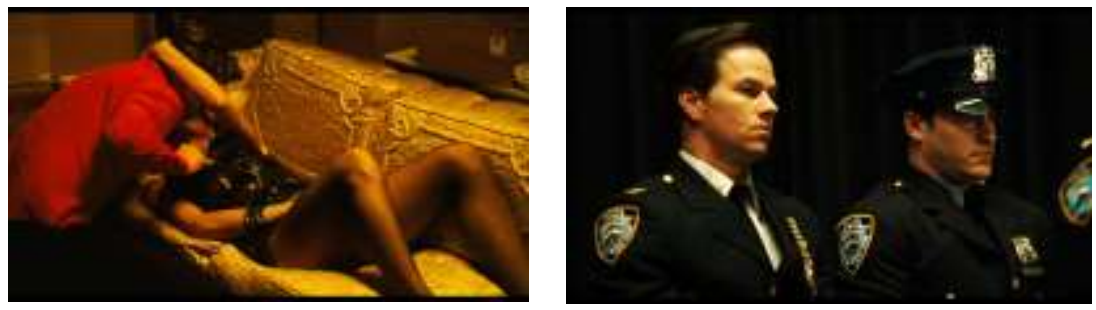

Figures 6 and 7. Color palette conveying Bobby's interiority 
The tragic cost is foregrounded aesthetically throughout the film, by such formal devices as slow-motion cinematography during Bobby's father's death to underscore the subjective perspective of the distressed protagonist; compositional framing and double-framing denoting entrapment and isolation; and stark chiaroscuros suggesting the inner anguish of the leading character, provoked by the dark reality surrounding him. ${ }^{8}$ These cinematic techniques convey Bobby's dilemma of choosing a side and the tragic cost of having to protect his family, which stage the tension between self-assertion and social determination. Film noir has long presented alienated individuals and an overall cynicism and pessimism regarding social change "not simply as personal flaws," as Shaun Anne Tangney notes, "but as evidence of a systemic or ideological failure, the failure of the American dream" $(2012,202)$. We Own the Night partakes of this trend of (neo)noir cinema, which can be explained not (just) by looking at the conventions of the genre and how Grey adapts them to his personal style, but also by considering the director's socio-cultural background, as part of what has become known as Generation X.

Born in the 1960s and 1970s, Generation X is the generation that followed the so-called Baby Boomers and that came into age at the time when, as Peter Hanson notes, the idealism of the sixties had vanished, after a failed war in Vietnam, the Watergate scandal, and various conflicts that marked a "darkening of modern society" (2002, 10). Hanson includes James Gray among Gen $X$ filmmakers, arguing that "their collective body of work" functions "as a reaction to the forces that shaped their generation as a whole" $(2002,5)$. According to Hanson, their major preoccupation is the self, and the questions they ask are "Who am I, and where do I belong?" $(2002,6)$. He also points out that many of their films deal with the "difficult transition from childhood to maturity" $(2002,2)$. In this context, Bobby can be seen as one of the "disaffected characters in Gen-X movies," his role as madcap Hal making him akin to the "quintessential Gen- $X$ archetype: the slacker" (Hanson 2002, 7-11). Moreover, aesthetically and ideologically, We Own the Night is analogous to Gray's previous film, The Yards (2000), and both form part of his crime tragedy alongside

\footnotetext{
${ }^{8}$ Edward Hopper, a key influence in film noir, is one of the most notable visual referents denoting isolation and entrapment in Gray's cinematic oeuvre, together with the poetical realism of Helen Levitt's photography.
} 
his first feature film, Little Odessa (1994). According to Christophe Gelly, The Yards "reproduces a discourse of social victimization that was at the basis of the noir tradition, dealing mainly with underdogs who fail to escape their own condition" $(2011,460)$. This reading of the film corresponds to Hanson's, who notes how the protagonist is impelled to betray his humanity when confronted with a moral catch 22 , which in this case is having to choose between his family and the law $(2002,125)$. Interestingly, The Yards concludes similarly to We Own the Night: with a circular narrative movement that denotes entrapment. While the film opens with the protagonist at the moment when he is released from jail, it closes with him dolefully still, reflexive, and in silence, just after testifying in court against the criminal acts certain members of his family had committed. In both cases he is travelling by train, which is the key site of corruption in The Yards.

If gangsters are fated to remain in the world of crime according to film noir conventions, Bobby is determined by the class structure, which is the middle-class sphere of his police family. It could be argued that the protagonist voluntarily decides to side with his family, but the film does register the cost and tragic coerciveness of that "choice." By presenting the final celebratory event in a tragic manner, the film disrupts the normative binary structure of failure and success. Bobby simultaneously fails his girlfriend and friends and succeeds in avenging his family. Since choosing a side is fraught with loss, Bobby's dilemma underscores the societal obstacles imposed on the self and the limits of individual freedom. The film distances itself from the police procedural film genre and focuses on the subjectivity of the leading character, showing his development and registering his angst and pain, instead of the minutiae of police-work. This focus on the family is a variation on the noir genre that Gray has introduced, as Christophe Gelly argues, also in relation to The Yards (2011, 461). ${ }^{9}$ The family is an underlying concern of Generation $X$, whose filmmakers "generally starved for a sense of family" (Ortner 2013, 134). Their cinematic output focuses on "families that are deeply dysfunctional" and stresses "the importance of surrogate families" (2013, 131-34). Gray's cinematic output shows a constant

\footnotetext{
${ }^{9}$ As Chopra-Gant notes, the family is a "largely absent entity" $(2005,161)$ in film noir, despite the importance of the surrogate families in works such as The Godfather.
} 
preoccupation with the family, a motif present from his first feature film, Little Odessa, to the last one to date, The Lost City of Z (2016).

We Own the Night transposes the (neo)noir tension between selfassertion and over-determination to the domestic sphere and moves from a Manichean understanding of absolute freedom versus total containment. The film locates the family as a site of order and authority with Bobby Green (or rather, Robert Grusinsky) mirroring Prince Hal's journey of accepting his place in the family and in society at large. Juxtaposing a dysfunctional family with a city torn by crime, the film foregrounds the connection between the private sphere of domesticity and the public one. In doing so, We Own the Night interrogates the notions of fate and freedom well beyond the private domain of the self and the family. According to James Gray, "social mobility and self-invention is doomed from the start," a view that questions key ideas of freedom and individuality that are crucial components of the American Dream, the dream "of a better, richer, and happier life for all our citizens" (Adams 1931, xx). This questioning of absolute freedom and individuality lies at the heart of We Own the Night, since it presents choice as limited and fraught with loss. The director himself explains that the tragic dimension of the film is "informed mostly by post-1968 poststructuralist thinking." Gray uses this framework to explain what he perceives to be the contemporary understanding of fate, as he notes:

As far as the idea of free will goes, the major thing I came across was the writing of Louis Althusser. He spoke about the fact that we are beholden to an ideological state apparatus. Your ability to decide for yourself - good and evil, do I turn left or right, this product is what I want, this is what I want to watch - all this stuff is not about you choosing. It's about the way you have been programmed from birth by culture, language and ideology. Your expectations and your desires are not your own, really; they have been created for you. I found this to be very powerful. If you combine that notion with the central Horatio Alger myth, you've got two ideas that are totally in conflict, and are destined to create resentment. (Gray 2011, n.p.)

When viewed in this framework, Bobby's tragedy is an individual embodiment of the tragedy of a delusive socio-political system that, far from granting one's freedom, imposes an order. Located at the core of this system, the family functions as a site of entrapment and as a determiner of identity in a film that, following James Gray's comments in the press, can be read in Althusserian terms: as a 
depiction of a social system according to which individual freedom is constraint and the social structure is as determining of our choices as it is of our ability to choose. The interpellation mechanism, via ideology, supplies society with subjects that occupy an assigned role in the system while believing they are completely free individuals. This Althusserian vision underpins We Own the Night, as the film presents the process of interpellation of an individual (i.e. Bobby) who is determined by dominant ideology and forced to take a side; progressively, he is "hailed" as Robert Grusinsky.

According to Althusser, the family takes a leading role in the process of securing the system, disseminating ideology and constructing identity: institutions such as education, religion, the media, and the family, among others, constitute the Ideological State Apparatuses (ISAs), which become entwined with the so-called Repressive State Apparatuses (RSAs), like the army and the police, whose assigned role is to implement the ideology of the state through the use of violence $(1971,96-97)$. A representative instance of each apparatus at work is directly present in the film: both an ISA, the family, and an RSA, the police, constrain Bobby and mark his struggle in the private and the public sphere. The repressive nature of the RSA is overtly exposed in the violent raid on El Caribe, during which the police physically attack Bobby. Through the use of violence, the police coerce Bobby to cooperate, but he resists and ends in prison (another RSA). His family had tried before to make him cooperate, in an instance of ideological constraint that the film, meaningfully, situates in a church - pointing towards another ISA, religion.

The combination of ideological and repressive forces determines Bobby's siding with the sphere of order and patrilineal family, symptomatically encapsulated in a frame of eloquent composition: Bobby's image is not just enmeshed in a trapping structure dominated by the police's badge, but also diminished and marginalized by it. It is a shot that foresees how, ultimately, the structure affects his enrolment as a police officer. Indeed, shots which frame Bobby as pictorially diminished and decentered by the surrounding architecture pervade the film. 

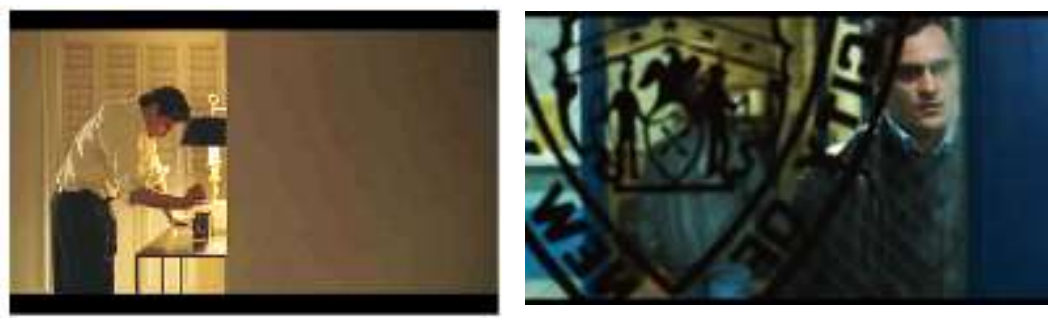

Fig. 8 and 9: Structural oppression of Bobby is conveyed cinematographically with shot composition.

With Bobby as a postmodern individual determined by a system that limits free choice in an ideologically constraining society, this cinematic interpretation of the Henriad can be placed alongside that of Jan Kott, since both Gray and Kott read the texts as tragedies whose protagonist is the system, or what the Polish theoretician calls "History." According to Kott, the core of Shakespeare's historical plays is the Grand Mechanism of History, a device in which human life is meaningless and identity hollow, with individuals being assigned a given slot in the structure. Characters are subjects assigned a role in a system that erodes individual freedom: "there is only the king's situation, and the system. This situation leaves no room for freedom of choice" (Kott 1967, 14). In other words, subjects are interpellated into a system where they function as "cog-wheels in the Grand Mechanism" (Kott 1967, 28). But Kott does not deny human agency completely, as he understands this perverse mechanism to be originated by a Machiavellian person, with which an Althusserian reading may converge: the tragedy of the Grand Mechanism is the tragedy of realpolitik, of a certain political system that constrains individuals, forced to occupy a certain subject position, or a given slot in the structure. In sum, "the implacable roller of history crushes everybody and everything. Man is determined by his situation, by the step of the grand staircase on which he happens to find himself. It is that particular step that determines his freedom of choice" (Kott 1967, 39), although the perpetrator of such entrapment is, in the end, another human agent. Writing during the Cold War from Poland, Kott adapted the Henriad to the socio-political context of Poland during the late 60s. Similarly, James Gray views the Henriad through the lens of a Gen-X camera, and thus emphasizes the limited choice individual at the time had given the precariousness of the socio-economic situation. Following the dominant forces of ideology, Hal-as-Bobby is 
interpellated and tragically led to occupy a subject position. He faces a limiting choice between two opposing spheres and the film poignantly registers the cost of such a choice through the banishment of the Falstaff figure. The loving Puerto Rican partner functions as the scapegoat and signals the emotional cost of the Grand Mechanism. The film's interpretation of the Henriad questions the reality of freedom and individuality from the perspective of the Generation X, for whom "the American Dream was but a long gone and foreign past" (Lee 2010, 21), entering thus into dialogue with its sociocultural context. As a consequence, the film challenges the conventional categories of success and failure, breaking down the dichotomy since the protagonist simultaneously succeeds in avenging his family and fails, since this success happens at the cost of leaving part of his life behind.

\section{Conclusion}

This article demonstrates that We Own the Night functions as a sustained and sophisticated retelling of the Henriad. Drawing mainly from Hal's story in 1 Henry IV, the film functions as a Shakespeare adaptation that transposes the Henriad to a police context. It presents the story of Prince Hal with a tripartite Falstaff, a split Hotspur and a series of climactic events that cinematographically correlate to key scenes in Shakespeare's play. This article argues that We Own the Night updates the Henriad as a (post)modern tragedy from an Althusserian perspective to question how the constraining forces of society determine the individual, mobilizing the concerns of the so-called Generation X. Taking an Althusserian perspective, James Gray rewrites a story in which Hal, far from being a Machiavellian character, is the victim of his socio-political circumstancesparadoxically succeeding through failing, as registered through the tragic cost of "banishing" Amada while becoming a policeman. In this way, the adaptation aligns itself with Jan Kott's seminal interpretation of Shakespeare's play. Analyzing We Own the Night in the light of poststructuralist theorizations of ideology and in relation to Kott's insights can significantly enhance our understanding of the film's engagement with the Henriad and of the contemporary approaches undertaken to adapt Shakespeare on screen. 


\section{Sánchez-García}

\section{References}

Adams, James Truslow. (1931) 2012. The Epic of America. Washington D.C.: Library of Congress.

Alpert, Robert. 2012. "The Films of James Gray: Old Testament Narratives." Senses of Cinema 65. Accessed October 30, 2018. http://sensesofcinema.com/2012/feature-articles/the-films-of-jamesgray-old-testament-narratives/

Althusser, Louis. (1971) 2001. "Ideology and Ideological State Apparatus." Translated by Ben Brewster. In Lenin, Philosophy and Other Essays, edited by Louis Althusser, 85-126. New York: Monthly Review Press.

Aragay, Mireia. 2015. "Introduction. Reflection to Refraction: Adaptations Studies Then and Now." In Books in Motion: Adaptation, Intertextuality, Authorship, edited by Mireia Aragay, 11-32. Amsterdam: Rodopi.

The Bad Sleep Well. 1960. Directed by Akira Kurosawa. Toho Company.

Burnett, Mark Thornton. 2013. “Re-reading Akira Kurosawa's The Bad Sleep Well, a Japanese Film Adaptation of Hamlet: Content, Genre and Context." Shakespeare 9 (4): 404-17.

Calbi, Maurizio. 2013. Spectral Shakespeares: Media Adaptation in the Twenty-first Century. New York and Basingstoke: Palgrave.

Campillo Arnáiz, Laura. 2015. "Recycling The Tempest in Tron:Legacy." In Shakespearean Echoes, edited by Adam Hansen and Kevin J. Wetmore Jr., 120-29. New York and Basingstoke: Palgrave.

Cartelli, Thomas, and Katherine Rowe. 2007. New Wave Shakespeare on Screen. Cambridge: Polity Press.

Catania, Saviour. 2017. "Spectres of Film Adaptation: A Hauntology of Relational Hybridity." LFQ 45 (2): n.p.

Chopra-Gant, Mike. 2005. Hollywood Genres and Postwar America: Masculinity, Family, and Nation in Popular Movies and Film Noir. London: I.B. Tauris.

Gelly, Christophe. 2011. “The Yards (James Gray, 2000): Neo-noir as Generic Hybrid." Études Anglaises 64 (4): 455-64.

Grady, Hugh. 2000. "On the Need for a Differentiated Theory of (Early) Modern Subjects." In Philosophical Shakespeares, edited by John J. Joughin, 35-52. London: Routledge.

Gray, James. 2007. Interview with Andrew O'Hehir. Salon, October 11. Accessed March 18, 2017. http://www.salon.com/2007/10/11/btm_13/

Gray, James. 2007. Interview with Serge Kaganski. Les Inrockuptibles, November 28. Accessed August 26, 2013. http://www.lesinrocks.com/cinema/films-a-l-affiche/la-nuit-nousappartient/ 
Greenblatt, Stephen. 1980. Renaissance Self-Fashioning: From More to Shakespeare. Chicago: Chicago University Press.

Halberstam, Jack. 2011. The Queer Art of Failure. Durham: Duke University Press.

Hanson, Peter. 2002. The Cinema of Generation X: A Critical Study of Films and Directors. London: McFarland.

Kastan, David Scott. 2002. "Introduction." In King Henry IV Part 1, Arden Shakespeare $3^{\text {rd }}$ series, edited by David Scott Kastan, 1-131. London: Bloomsbury.

Kott, Jan. (1967) 1994. “The Kings.” In Shakespeare our Contemporary, translated by Boleslaw Taborski, 3-46. London: Routledge.

Lanier, Douglas. 2016. "Shakespeare and the Indie Auteur: Michael Almereyda and James Gray." Shakespeare Bulletin 34 (3): 451-68.

Lanier, Douglas. 2014. "Shakespearean Rhizomatics: Adaptation, Ethics, Value." Shakespeare and the Ethics of Appropriation, edited by Alexa Huang and Elizabeth Rivlin, 21-40. New York: Palgrave.

Lee, Christina. 2010. Screening Generation X: The Politics and Popular Media of Youth in Contemporary Cinema. Farnham: Ashgate.

Leitch, Thomas. 2008. "Adaptation Studies at a Crossroads." Adaptation 1 (1): 63-77.

Leitch, Thomas. 2017. “The Place of 'Literature and Film' Today.” LFQ 45 (2): n.p.

Lim, Dennis. 2007. “An Auteur for a Neglected New York City.” The New York Times, September 9, A46.

Little Odessa. 1994. Directed by James Gray. Fine Line Features.

Melchiori, Giorgio. 2007. "Introduction." In The Second Part of King Henry IV. New Cambridge Shakespeare, edited by Giorgio Melchiori, 1-73. New York: Cambridge University Press.

Mintzer, Jordan. 2012. Conversations with James Gray. Edited by David Frenckel. Paris: Synecdoche.

Naremore, James. 2000. "Introduction: Film and the Reign of Adaptation." Film Adaptation, edited by James Naremore, 1-16. New Brunswick, New Jersey: Rutgers University Press.

Ortner, Sherry B. 2013. Not Hollywood: Independent Film at the Twilight of the American Dream. Durham: Duke University Press.

Ray, Robert B. 2000. "The Field of 'Literature and Film'." In Film Adaptation, edited by James Naremore, 38-53. New Brunswick, New Jersey: Rutgers University Press. 


\section{Sánchez-García}

Scott, A.O. 2007. "2 Brothers, and the Mob in the Middle." New York Times, October 12, E18.

Stam, Robert. 2015. "Introduction: The Theory and Practice of Adaptation." In Literature and Film: A Guide to the Theory and Practice of Film Adaptation, edited by Robert Stam and Alessandra Raengo, 1-52. Oxford: Blackwell.

Stam, Robert. 2017. “The Changing Pedagogies of Adaptation Studies.” LFQ 45 (2): n.p.

Strange Illusion. 1945. Directed by Edgar G. Ulmer. PRC.

Tangney, ShaunAnne. 2012. “The Dream Abides: The Big Lebowski, Film Noir, and the American Dream." Rocky Mountain Review 66 (2): 176-93.

Tron:Legacy. 2010. Directed by Joseph Kosinski. Walt Disney Pictures.

We Own the Night. 2007. Directed by James Gray. Columbia Pictures.

Weil, Herbert, and Judith Weil. 2007. "Introduction." In The First Part of King Henry IV, edited by Herbert Weil and Judith Weil, 1-79. New Cambridge Shakespeare. New York: Cambridge University Press.

The Yards. 2000. Directed by James Gray. Miramax.

How to cite this article:

Sánchez-García, Inmaculada N. "Uneasy lies the heart that wears a badge: James Gray's We Own the Night as a Gen-X Henriad." SEDERI 29 (2019): 135-50.

https://doi.org/10.34136/sederi.2019.6

Author's contact: inmaculada.n.sanchezgarcia@gmail.com

Postal address: Northumbria University - Sutherland Building - Newcastle-upon-Tyne - NE1 8ST - UK

Submission: $31 / 10 / 2018$

Acceptance: 26/03/2019 